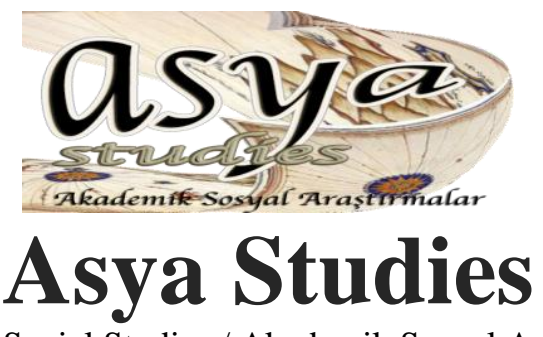

Academic Social Studies / Akademik Sosyal Araştırmalar

Year: 5 - Number: 17, p. 77-90, Autumn 2021

\title{
The Views of Instructors on the Organizational Climate at the School of Foreign Languages*
}

\author{
Öğretim Görevlilerinin Yabancı Diller Yüksekokulu Örgüt İklimine Yönelik
}

DOI: https://doi.org/10.31455/asya.942305

\author{
Görüşleri
}

\author{
Araştırma Makalesi / \\ Research Article

\begin{abstract}
Makale Geliş Tarihi /
Article Arrival Date
\end{abstract} \\ 24.05.2021
}

\begin{abstract}
Makale Kabul Tarihi /
Article Accepted Date
\end{abstract}

15.07.2021

Makale Yayın Tarihi /

Article Publication Date

29.09.2021

\section{Asya Studies}

Lect. Sinem Arslan Dönmez

Alanya Hamdullah Emin Paşa

University, School of Foreign

Languages

ssinem.arslan@gmail.com

\section{ORCID ID}

https://orcid.org/0000-0003-4816-420X

* This study is adapted from the nonthesis master's project titled "Vakıf Üniversitelerindeki İngilizce Öğretim Görevlilerinin Yabancı Diller Yüksekokulu Örgüt İklimine Yönelik Görüşleri. In addition, the Ethics Committee Approval Information of this study was declared before the References section.

\begin{abstract}
Öz
Araştırmada vakıf üniversitelerinin yabancı diller yüksek okulu bünyesinde çalışan öğretim görevlilerinin örgüt iklimine yönelik görüşlerinin ve bu görüşleri etkileyen unsurların neler olduğu belirlenmeye çalışılmıştır. Çalışmada nitel araştırma yöntemlerinden fenomenoloji (olgubilim) deseni kullanılmıştır. Veriler Ankara'da bulunan dört farklı vakıf üniversitesinde çalışmakta olan sekiz İngilizce öğretim görevlisinden elde edilmiștir. Katılımcılar ölçüt örnekleme yöntemi kullanılarak belirlenmiştir. Bu bağlamda, öğretim görevlilerinin yabancı diller yüksekokulunda hâkim olan iklimi gözlemek ve değerlendirmek için kurumda yeterince zaman geçirmiş olmaları gereği göz önünde bulundurulmuş ve en az bir yıldır mevcut yönetici ile çalışıyor olmak koşulu ölçüt olarak belirlenmiştir. Katılımcılardan sağlanan verilerin analizi sürecinde içerik analizi ve betimsel analiz yöntemlerinden faydalanılmıştır. Yapılan analizler sonucunda örgüt iklimi olgusunun örgütsel yapı ve yönetim sistemi, liderlik ve örgüt içindeki iletişimden etkilendiği tespit edilmiştir. Veri analizi sonucunda ayrıca yabancı diller yüksekokullarında en fazla kullanılan güç kaynağının yasal güç olduğu ve bu durumun çoğunlukla kapalı ve otokratik bir örgüt iklimi algısına sebep olduğu belirlenmiştir. Son olarak ise çalışanlar arasındaki ilişkilerin yönetici-çalışan ilişkilerine göre daha olumlu özellikler taşıdığı tespit edilmiştir. Sonuç olarak, yabancı diller yüksekokulu bünyesinde olumlu olarak algılanmakta olan insan kaynağının, etkili ve verimli bir yönetim sayesinde örgütsel hedefler doğrultusunda başarılı şekilde harekete geçirilebileceği söylenebilir.
\end{abstract}

Anahtar Kelimeler: Örgüt İklimi, Yabancı Diller Yüksekokulu, Yükseköğretim, Öğretim Görevlisi, Vakıf Üniversitesi

\section{Abstract}

The purpose of this study is to investigate the views of university instructors on organizational climate. The phenomenology pattern was used in this study to reveal the events that instructors experienced related to the organizational climate and the meaning they attributed to these events. The criterion sampling method, one of the purposive sampling methods, was used in this study. Eight instructors of English working at the school of foreign languages of four different foundation universities in Ankara in $2017-$ 2018 academic year took part as the participants in this study. The qualitative data was collected via the interviews. Content analysis and descriptive analysis methods were used in the process of data analysis. The findings from the analysis showed that the organizational climate was affected by the organizational structure and management style, leadership and the communication networks. The findings from the analysis also showed that the most common power source was legal power and this situation mostly caused instructors to feel a closed and autocratic organizational climate. However, the relations among employees had more positive characteristics in comparison to the relation between administrators and the employees, so improving management styles could contribute to the efficiency of the school of foreign languages.

Keywords: Organizational Climate, School of Foreign Languages, Higher Education, Instructors, Foundation University 


\section{INTRODUCTION}

Organizational climate is a concept that is frequently used in studies related to the field of organizational behavior and has been defined in various ways by different researchers. Litwin and Stringer (1968) defined organizational climate as the measurable priorities that organizational members perceive in the work environment and that are assumed to affect their motivation and behavior. According to Ertekin (1978), organizational climate refers to the way employees perceive the situation and conditions that exist in an organization and affect the behavior of employees. Varol (1989) states that organizational climate is the atmosphere created by organizational culture within the organization. According to Çelik (2000), organizational climate is the characteristics that are perceived by the employees and dominate the organization. Lunenberg and Ornstein (2013) define the organizational climate as the whole of all environmental characteristics within an organization. Schneider and Barbera (2014), on the other hand, define organizational climate as the social and psychological states felt by employees within the organization.

Litwin and Stringer (1968) state that the organizational climate is the result of elements such as structure, responsibility, support, rewarding, and risk in the organization. The first of these elements is organizational structure. Organizational structure is the formal and informal structures such as rules, regulations, methods and constraints that employees feel within the organization. Second element, responsibility, is whether the employees are actually responsible for the work they do or not. The third important element in the organizational climate is support. Support indicates whether there are supportive and respectful relationship among employees and between employees and administrators within the organization. Another important factor for the organizational climate is rewarding. Rewarding can be expressed as how the work done by the employee is appreciated. An organization with a fair rewarding system and objective practices is perceived as a positive atmosphere by employees; however, an organization in which arbitrary rewarding practices are applied, and fairness is ignored is perceived as having a negative climate (Özçiçek, 2016). Finally, risk taking is important for productivity and high performance, as it enables employees to act without fear about innovations (Büte, 2011).

The concept of organizational climate, which was first used in the study conducted by Lewin and his friends in 1939 to indicate the feelings and social consequences of the behaviors of the leaders on the summer camp participants, became important in the field of administration especially after the 1960s and many researches have been conducted on the concept. That the organizational climate is perceived in different shapes and levels by the members of the organization has brought along many different organizational climate classifications. In this study, the climate types including open, autonomous, controlled, familial, paternal and closed climates suggested by Halpin (1966) were explained. An open climate describes the openness and authenticity of interaction within the organization. In an organization with an open climate, administrator shows real concern for the staff and gives freedom to them. Respect and help are important characteristics of open climate. Autonomous climate has an environment to give freedom to the employees to carry out their duties. Teachers and students feel motivated and happy in an autonomous climate. From time to time, formal relations could be faced in autonomous climate (Morrison, 2002). In the controlled climate, the administrator keeps their distance from the staff and the students. Hard work is the focus of this climate profile. Familiar climate shows a laissez-faire atmosphere. As the administrator tries to maintain a friendly relation with the staff, some members of the organization are not committed to their primary duties. Paternal climate depicts an atmosphere where the administrator is quite hard working, but has no effect on the staff. Although there is closeness between the administrator and the staff, the expectations from the staff are not very practical, so the staff keep a distance from the administrator. Closed climate is the opposite of the open climate. There is a lack of commitment and productivity in this climate profile. As the administrator is rigid, controlling, inconsiderate and unsupportive, the staff is ineffective and frustrated.

Studies done on the concept of organizational climate revealed its effect on various elements within the organization. Previous studies linked the organizational climate to turnover rate (Nartgün, 2006), organizational commitment (Çağlar, 2008; Thomas, 2008), the effectiveness of the organization and performance (Ekşi, 2006; Zhang and Liu, 2010), job satisfaction (Özdemir, 2006), service quality and outcomes (Glissorn and Hemmelgarn, 1998), leadership (Ayık and Şayir, 2014) and mobbing (Yaman, 2010). There have conducted studies focusing especially on the impact of organizational climate on the educational institutions. The findings of these studies have proven that there is a relationship between the organizational climate and teachers' performance (Halpin and Croft, 1966; Raza, 2010), teacher 
effectiveness (Babu and Kumari, 2013), openness to innovation (Oldham and Cummings, 1996), leadership features in educational institutions (Ay1k and Şayir, 2014) and the success of the students (Chen and Weikart, 2008; Jones and Shindler, 2016). Few researches on the organizational climate in higher education in Turkey have also been conducted (Arabac1, 2011; Bucak, 2002; Gül, 2008; Kasırga and Özbek, 2008; Özdede, 2010; Süslü-Kalafat, 2017; Ural, 2014). However, most of these studies were conducted as quantitative ones and aimed to reveal the level of the organizational climate and its relation to different variables, so the number of qualitative studies focusing on understanding the organizational climate and the factors deeply affecting it especially in school of foreign languages of foundation universities is very limited. In his study, Arabac1 (2011) concluded that faculty's perception of organizational climate is low in the organizational communication dimension. In his study conducted by Bucak (2002), it was found that the subordinate-superior relations under the management of the faculty staff occur at medium and below-average levels in terms of organizational climate. Gül (2008), on the other hand, evaluated the climate of their organizations as generally moderate in terms of rules and discipline, democracy, social and cultural factors, organizational image and organizational goals. Ural (2014) concluded that the perception of organizational climate of Gazi University staff is medium and below. The study conducted by Tofur and Balıç̧ı (2018) was the only qualitative study on organizational climate and higher education. As a result of their study, they conducted that school's socioeconomic environment, individualism among employees, unfair managerial attitude, communication problems and educational legislations cause negative climate while dignification of the staff, effective communication, participation of the staff on decision-making, fairness of the administrators and awareness of duties and responsibilities contribute to positive climate.

\section{Purpose of the Study}

The study aims to find out the perceptions of instructors of English working in the school of foreign languages of foundation universities towards the organizational climate and the elements affecting their perception. In this sense, the answers of the following questions have been investigated:

1) What are the problems encountered within the organization?

2) What are the positive features within the organization?

3) Which power sources are used by the administrators?

4) What are the views of instructors towards administrators, colleagues and the organizational climate?

The existence of a constructive climate is important for an organization to perform its functions effectively. Especially in educational institutions where employees act as the role models of the learners, creating a positive environment is vital for the execution of educational activities in accordance with the purpose of the institution. In this perspective, it is believed that this study will make contributions to increasing the effectiveness of education at school of foreign languages by revealing the views of instructors about the organizational climate and the factors that affect these views.

\section{METHOD}

\section{Research Design}

This study aims to investigate the views of instructors towards organizational climate. Therefore, a qualitative research method was used in this study. In a qualitative study, the aim is to explain the subject in a deep, realistic and detailed way (Patton, 2002; Yıldırım and Şimşek, 2016). In this study, which aims to examine the views of instructors of English working in schools of foreign languages towards the organizational climate, phenomenology, one of the qualitative research designs, was used. Phenomenology is carried out with the aim of revealing the importance or meaning that a person or group gives to the experiences they have lived or the concepts they encounter, and it aims to explain the participants' subjective judgments, experiences and the meanings they attribute to these experiences (Patton, 2002).

\section{Participants}

Eight instructors of English working in the school of foreign languages of four foundation universities in Ankara took part as the participants of the study. The criterion sampling method was used in order to determine the participants of the study. To have been working with the current administrators for at least one year was the criterion to participate in the study. The demographic features of the participants are given in Table 1. 
Table 1. Demographic Features of the Participants

\begin{tabular}{|c|c|c|c|c|c|c|c|c|}
\hline Feature & I1 & I2 & I3 & I4 & I5 & I6 & I7 & I8 \\
\hline Gender & Female & Female & Female & Female & Male & Female & Male & Male \\
\hline Education & BA & BA & BA & MA & MA & $\mathrm{PhD}$ & MA & MA \\
\hline $\begin{array}{l}\text { Number of } \\
\text { administrators }\end{array}$ & 6 & 6 & 10 & 10 & 1 & 1 & 5 & 5 \\
\hline Age & 32 & 29 & 29 & 32 & 32 & 34 & 32 & 29 \\
\hline $\begin{array}{l}\text { Experience in the } \\
\text { institution }\end{array}$ & 2 yrs. & 4 yrs. & 5 yrs. & 5 yrs. & 5 yrs. & 6 yrs. & 5 yrs. & $5 \mathrm{yrs}$. \\
\hline
\end{tabular}

When the data of the study are examined, as shown in Table 1, the demographic data of the study show; five of the participants in the study were female and 3 were male. The ages of the participants ranged from 29 to 34. One of the participants was a doctorate holder, three of them had master's degrees and four of them were BA holders. The number of administrators in the school of foreign languages, where they worked, varied between 1 and 10 , and the experience at the current institution varied between 2 and 6 years.

\section{Data Collection and Tools}

In this research, the data were gathered through interviews between June 2018 and September 2018. The participants were interviewed individually. A semi-structured interview form developed by the researcher was used in the interviews and interviews lasted between 45 minutes and 75 minutes. In the first part of the interview form, questions about the demographic features of the participants were included. In the second part, six open-ended questions about the problems of the research were included:

1) What administrative problems do you have in your current institution?

2) What are the features that satisfy you in your current institution?

3) Which sources of power are most commonly used by your administrator?

4) Define your administrator in your current institution using a metaphor?

5) Define your colleagues in your current institution using a metaphor?

6) Define the organizational climate in your current institution using a metaphor?

Within the scope of four sub-problems of the study, it was aimed to reveal the first sub-problem of the study with the first interview question; the second sub-problem with the second interview question; the third sub-problem with the third interview question and the fourth sub-problem with the fourth, fifth and sixth interview questions.

\section{Data Analysis}

In this study, descriptive and content analyses were used to analyze the data. In the descriptive analysis process, first of all, a thematic framework was created based on the conceptual structure of the research and the research questions. According to this thematic framework, the data were compiled in a meaningful and logical way. Yıldırım and Şimşek (2016) state that content analysis can be used to reveal the concepts and facts that remain hidden during the descriptive analysis by examining the data organized with descriptive analysis in more depth and revealing the concepts and themes that are not noticed before. In this context, the data were coded with content analysis and the final themes were obtained based on the relationships between the codes and the findings were defined. While coding, coding within general framework recommended by Strauss and Corbin (1990) was used (Yıldırım and Şimşek, 2016). In this type of coding, although the data is coded according to the conceptual structure created before the data analysis, new codes that emerge during the analysis are included in the list. In this context, the participants' answers were re-examined in detail and new themes were created and the final version of the findings were interpreted. In addition, descriptive direct quotations were included in the study in order to reflect the thoughts of the participants (Yıldırım and Şimşek, 2016).

\section{Validity and Reliability}

In order to increase the reliability of the study, the notes created by the researcher were shared with the participants and the participants confirmed that the notes reflected their opinions accurately. In addition, the themes and codes created by the researcher were cross-checked with an expert within the field of educational management and the consistency between themes and codes was measured. In this 
context, the reliability analysis suggested by Miles and Huberman (1994) was used. As a result of the analysis, the rate of similarity in the whole study was determined as $90.00 \%$. Participation in the study was carried out on a voluntary basis. At the beginning of the study, each participant filled in a "Participant Consent Form". In addition, it was ensured that the information collected will be kept confidential and will only be used for research purposes. In order to keep the personal information of the participants confidential, codes such as I1, I2 were used for each participant.

\section{FINDINGS}

In this section, the findings having emerged during the data analysis process in the scope of the research questions were presented under six categories including (1) Problems encountered in the working environment, (2) Satisfactory features in the working environment, (3) Common power sources used by administrator, (4) The metaphors for administrators, (5) The metaphors for colleagues and (6) The metaphors for the organizational climate.

\section{Problems Encountered in Working Environment}

The problems encountered in the working environment are given in Table 2.

Table 2. Problems Encountered in Working Environment

\begin{tabular}{|c|c|c|c|c|c|c|c|c|}
\hline Theme & I1 & $\mathbf{I 2}$ & I3 & I4 & I5 & I6 & I7 & I8 \\
\hline Administrator Related problems & $\checkmark$ & & $\checkmark$ & $\checkmark$ & & & $\checkmark$ & $\checkmark$ \\
\hline Communication Related Problems & & $\checkmark$ & & & $\checkmark$ & $\checkmark$ & $\checkmark$ & \\
\hline $\begin{array}{l}\text { Organizational Structure Related } \\
\text { Problems }\end{array}$ & & $\checkmark$ & & $\checkmark$ & & $\checkmark$ & & $\checkmark$ \\
\hline
\end{tabular}

In Table 2, it is seen that participants stated their opinions about the problems encountered in working environment under the themes of administrator related problems, communication related problems and organization structure related problems. Most of the problems were caused by the administrators. The most important reasons for the problems were the unfair administrative approach and the lack of appreciation for the opinions of the employees. In this regard, the participants stated the following:

"I can say that the biggest problems we encounter are caused by the administration. In fact, they do not care about the opinions of anybody other than themselves and try to impose only their opinions on us." (II)

"He/She discriminates and has an unfair administrative style; So, in his/her mind, he/she divided us into two groups, those who love and those who do not, and, he/she certainly mistreats and gives more duties to those who do not like him/her. Those who love him/her are treated mildly. "(I7)

"I think there are serious problems about being fair to employees. I observe that situations such as recruiting, dismissing, granting extra responsibility, rewarding high performance are mostly unfortunately dependent on bilateral relations, not according to any criteria". (I8)

Another administrator-related problem was stated as the administrator's lack of leadership qualifications. Statements on this subject are as follows:

"I think, due to her personality, she is not a very suitable person for leadership as she, without any basis, pilot implementation or preliminary research, can make extremely arbitrary and sudden decisions." (I7)

"I think there is a serious lack of leadership especially in change / transformation and decisionmaking processes." (I8)

The next administrator related problem is the autocratic administration. Participants state as follows on this issue:

"Because in fact, they do not care about the opinions of anybody other than themselves and try to impose only their opinions on us." (II)

"We have problems due to the fact that the administrators want everybody to act only according to their will and the unit does not raise much noise against it. Our manager has intention to make us work not by using the knowledge or by motivating us in various ways but by using various sanctions. An 
administrative approach that insists on implementing one's own ideas rather than a participatory decision-making mechanism prevents us from feeling valuable. "(I3)

"I observe that decisions such as recruiting, dismissing, granting extra responsibility, rewarding high performance are mostly unfortunately dependent on bilateral relations, not according to any criteria." (I8)

Another administrative related problem is mobbing and ignoring employees' needs. About it I7 said "What bothers me most is that she is mobbing. She has a serious mobbing tactic or habit ... I mean, five of our colleagues who did their jobs very well and really deserved to be there had to leave because of her and due to direct or indirect reasons. Another friend of ours is still there with difficulty." and I4 stated "Another issue is that while some evaluations rely heavily on numerical data; cultural data about organizational structure such as human relations and social environment are not taken into consideration."

Secondly, organizational structure related problems were stated by the participants. I6 stated that unclear job descriptions in the organizational structure cause problems within the organization saying "In some duties, descriptions are not explained clearly. This can cause discomfort and uneasiness in the institution for us." I2, on the other hand, stated problems arising from having too many managerial positions within the organization, which creates a perception of unfair and unequal work among employees, saying "Having too many managerial positions and titles in the organizational structure is a problem: one coordinator, manager etc. for every 5-6 people. The position is the reason why equal work cannot be done. Some of them seem more privileged." I4 emphasized that frequent administrative and decision changes cause problems within the organization saying "Decisions can sometimes be changed very quickly. In addition, since we work with a young population, I am not sure whether these rapid decision changes can be a solution, since the changes in the management staff must be made in a way that does not disrupt the system due to reasons such as going on maternity leave and moving abroad." Another administrative problem is non-standard reward-punishment practices. I8, on this issue, said, "I observe that situations such as recruiting, dismissing, giving extra responsibility, rewarding high performance are mostly due to bilateral relations rather than any criteria."

Finally, communication-related problems were detected as a result of the analysis. In this regard, I5 said, "However, problems may occur as instructors work in different places (different buildings and campuses) or do not check their office mail regularly." I2 also says" Because we are very crowded, I think we cannot communicate well enough due to administrative inconveniences." I6 commented on this issue saying "Not very often, but I sometimes experience communication related problems. For example, expectations from me regarding the task cannot be expressed clearly." I7 expressed a communication related problem saying "And she can speak in a very impulsive and painful way without thinking or realizing the meaning of the words."

Positive Features in the Work Environment

The positive features of the working environment are shown in Table 3.

Table 3. Positive Features in the Work Environment

\begin{tabular}{lcccccccc}
\hline Theme & I1 & I2 & I3 & I4 & I5 & I6 & I7 & I8 \\
\hline $\begin{array}{l}\text { Communication among } \\
\text { employees }\end{array}$ & $\checkmark$ & $\checkmark$ & $\checkmark$ & & $\checkmark$ & & $\checkmark$ & $\checkmark$ \\
$\begin{array}{l}\text { Organizational structure } \\
\text { Colleagues }\end{array}$ & & & $\checkmark$ & $\checkmark$ & $\checkmark$ & $\checkmark$ & $\checkmark$ & $\checkmark$ \\
$\begin{array}{l}\text { The work itself } \\
\text { Administrator }\end{array}$ & $\checkmark$ & & $\checkmark$ & $\checkmark$ & $\checkmark$ & $\checkmark$ & $\checkmark$ & $\checkmark$ \\
\hline
\end{tabular}

As seen in Table 3, the participants consider one of the most important factors that affected the satisfaction of the employees in their current institutions was positive communication among the employees. Six of the participants referred to communication, organizational structure, colleagues, the work itself, and the administrator as can be seen in the following statements: school." (I1)

"Being in a team that I am happy to work with and communicate well makes me feel good at

"In general, I can say that I do not have any problems and I am happy when I become a partner with anyone in the institution. In general, I am satisfied with my colleagues in that sense. "(I2) 
"Besides, we work in a positive atmosphere, which creates satisfaction by creating a positive work environment." (I3)

"We are pleased to work in an environment where there is open communication. What I mean is, decisions are not just taken from the top and notified as written or verbal directives. Instead, we hold regular meetings about the decisions that need to be taken or the changes that need to be made. In these meetings, each of us can express his opinions clearly. And we can discuss. "(I5)

"I can say my colleagues. Of course, I am not very close to all the teachers, however; although I have met some of them through that university, they have a very important place in my life. I think these people are the greatest value the institution contributed to me, and they became very precious to me." (I7)

"My colleagues come first among the features that please me in the institution." (I8)

The second factor that satisfies the participants in the work environment was the factors related to the organizational structure. I3 said "We know for what purposes we will teach." and stated the pleasure to work in line with clearly defined goals. I4, on the other hand, said "The well-formed organizational chart and being able to take part in this chart are the most pleasing issue for me, which is not so common among instructors."

Another factor that makes employees pleased with the work environment is the opportunity to take responsibility and initiatives. Regarding this issue, I4 said "Teachers who want to take the initiative other than attend and teach the lesson and who are willing to take the responsibility can find appropriate tasks (program development unit, testing unit, professional development, educational technologies, etc.) and those who undertake these tasks have reduction in class hours. Regulations such as the opportunity to work in these offices do not make the person feel like they are standing still. On the contrary, it makes you feel that it is a developing and producing individual. "Another issue that pleases I4 is that the institution provides support for professional and academic development of the employees. I4 said "Another very important topic is that postgraduate studies are supported in all respects. It is an important decision for a foundation university with such a busy schedule to arrange schedules accordingly for day-offs for the instructors." I5 also stated that professional and academic development increased satisfaction saying "For example, new lecturers who have just started work can prepare material, etc. Under the mentorship of more experienced instructors, they are assigned to prepare materials. In addition, we have a manager who supports us in academic studies. All those who are accepted for MS/MA and PhD are in the priority field (there are also those who are out of the field) and their programs are arranged in a way that they are allowed at least half a day per week and allow them to attend these classes." I5 also said that the distribution of workload and responsibilities in the organization increases satisfaction saying "I am pleased that there is a division of labor and task sharing, and that some tasks are periodically performed between different instructors."

The third factor affecting the satisfaction of employees in the organization was the physical features and facilities in the organization. Regarding this issue, I7 said "We are not bad financially despite not being the university with the highest salary. In this context, I can count our salaries." I7 also stated that organizational values and the employees' own values contribute positively to the satisfaction of the employee saying "Whatever department you study in, you graduate by taking courses in other departments and other life skills-related subjects at our university - which is what I like very much. I8 also expressed his opinion on this subject saying "My educational philosophy is parallel with the philosophy of the institution".

Another issue that positively affected the satisfaction of the employees in the working environment was colleagues-related factors. I5 stated the importance of cooperation saying "I am happy to support each other, share workload and tasks". I6 said "Everyone participates in the study in a supportive way in order to meet the expectations of the institution. With a few exceptions, my colleagues are helpful, tolerant of error, and cooperative." I6 also stated that the sense of equality among employees increases satisfaction in the working environment saying "There is no difference in status with my colleagues, everyone works for common goals." I8, on the other hand, said "Equally passionate and excited colleagues make me happy". I7 focused on the importance of respect among colleagues saying "Our institution is a place where people can clearly experience their preferences in all matters such as religion, language, race, sexual orientation. Whether it is a political opinion or a sexual orientation, all our colleagues can openly share and live their views. This is another aspect that I love."

Another factor that positively affects the satisfaction in the work environment was identified as the administrators themselves. Participants' views on this issue are as follow: 
"Even though we have lots of administrators at various levels, I think that they also love their job and are not egocentric. I am happy in that sense." (I2)

"Even if there are some communicative problems related to administration that I mentioned above, they sort them out later." (I6)

The last factor affecting the satisfaction in the work environment is the work itself. Regarding this issue, I1 said "As an instructor, I feel good about seeing the change that students go through the year and the progress we have made in English language teaching within the framework of a common plan." and I3 said "It pleases me to see that the students are successful at the end of the year" I4, also, positively contributes to the satisfaction of the work environment as it offers the opportunity to put the knowledge they have gained through various trainings into practice saying "The fact that the opportunity to put what I have learned into practice in graduate programs is recognized in the workplace also creates an environment where we can make sense of these studies."

Common Power Sources Used by Administrators Table 4.

The most common power sources used by the administrators in the working place are given in

Table 4. Common Power Sources Used by Administrators

\begin{tabular}{|c|c|c|c|c|c|c|c|c|}
\hline Theme & I1 & I2 & I3 & I4 & I5 & I6 & I7 & I8 \\
\hline Legal Power & $\checkmark$ & & $\checkmark$ & & & $\checkmark$ & $\checkmark$ & \\
\hline Power of Expertise & & & & $\checkmark$ & $\checkmark$ & & & \\
\hline Coercive Power & & & & & & & & $\checkmark$ \\
\hline Powerlessness & & $\checkmark$ & & & & & & \\
\hline
\end{tabular}

In Table 4, it is seen that the most common power used by the administrators is legal power. It is also seen that the power of expertise, coercive power and powerlessness are used by administrators. However, there is no evidence of charismatic power and rewarding power according to the data in Table 4. The following sentences can be given as examples to the opinions of the participants to this theme:

"The most common power used is definitely the power they get thanks to their position. Whenever a decision is made, they say it is my decision as an administrator." (I1)

"They use their legal power." (I3)

"The most common power is assigning with their legal rights." (I6)

"While those who have a close relationship with the administration do not have a problem when they are late to a meeting, a warning is given immediately when someone from the other group comes late." (I7)

"Since he has a doctorate degree in the field of assessment, we always refer to his knowledge. Likewise, all kinds of information in the institution are statistically calculated, feedback is analyzed; student achievements and performance systems are created with the sensitivities of the measurement field. These numerical data make us feel the understanding of a fair approach." (I4)

"He is trying to convince us by revealing his own knowledge by providing information about innovations and trends in the field while making decisions on a new application." (I5)

"When there is something to be done, she prefers to give reference to the possible results of not doing it. What kind of punishments we can get is repeated again and again." (I8)

"I think powerlessness is used related to working hours, food, and roads." (I2)

Metaphors for Administrators

The metaphors that participants used to describe their administrators are shown Table 5.

Table 5. Metaphors for Administrators

\begin{tabular}{|c|c|c|c|c|c|c|c|c|c|}
\hline Metaphor & Image & I1 & I2 & $\mathbf{I 3}$ & I4 & I5 & I6 & $\mathbf{I 7}$ & I8 \\
\hline Dictator & autocratic, injustice & $\checkmark$ & & & & & & $\checkmark$ & \\
\hline Axe & Discouragement & & $\checkmark$ & & & & & & \\
\hline Politician & $\begin{array}{l}\text { care only their opinion, } \\
\text { making decisions alone }\end{array}$ & & & $v$ & & & & & \\
\hline Tree & support innovation and & & & & $\checkmark$ & & & & \\
\hline
\end{tabular}




\begin{tabular}{|c|c|}
\hline & progress \\
\hline Teacher & $\begin{array}{l}\text { high expectation, sincere } \\
\text { relations, discipline }\end{array}$ \\
\hline Traffic & ensuring order and \\
\hline Lamb & coordination, harmony \\
\hline Baseball & decisions not suitable for \\
\hline Bat & Turkey \\
\hline University & support progress, rules and \\
\hline Hospital & regulations \\
\hline
\end{tabular}

As seen in Table 5, six participants described their administrators with metaphors having relatively negative images. Two people used "dictator" metaphor for their administrators. In this regard, I1 said, "I can use dictators who do not agree with the opinion of others, who just try to impose their own opinion." while I7 said "A dictator who can make very sudden and last-minute changes and implementations, and there is a management style that supports discrimination and polarization." One participant associated the manager with the "axe" saying "Sometimes they can discourage the staff even in jobs they volunteer. Interruption and discouragement are points where we lose our enthusiasm." $\mathrm{I} 3$, on the other hand, used the metaphor "politician" saying "A politician who wholeheartedly believes that he is a democratic person, but only puts his own ideas into practice." Although I4 positively describes her administrator due to the opportunities he offers to the development of lecturers working in the institution and to develop new approaches, she used the metaphor of "faculty hospital" because of the seriousness and rules saying: "This is a place where doctors and doctor candidates who pursue their academic career do studies and try new approaches, as well as dealing with patients (students who want to learn languages and develop academic language). It is like an intense, faultless and highly disciplined place to work. This density does not allow much flexibility like hospital emergencies." I8 used "baseball bat" in order to emphasize the influence of American culture on the administration style of the administrator and said, "I think it has a meaning only in its own context, which is influenced by American culture."

Two participants described their administrators using positive metaphors. I5 said "I can say that he is a compassionate teacher who keeps the classroom in order and supports the education of students. Sometimes he is very loving, sometimes disciplined, and sometimes has high expectations, but in essence he is like a teacher who wants the good of the lecturers and wants to contribute to education."

I6 described her administrator with the metaphor of "traffic light" saying "He actually keeps things flowing properly. Thus, if we consider the workplace as traffic, the rules to be followed or the flow of traffic are largely under the management of the administrator. Of course, there are those who do not follow the red light and then the warning mechanism comes into play."

I4, who described the administrator as a "tree" due to its openness to innovations, and support for development said, "The essence of a tree does not change, but it has constantly new branches, the yield of the fruit changes according to that year but always gives fruit."

Metaphors for Colleagues

The metaphors that participants used to describe their colleagues are shown in Table 6.

Table 6. Metaphors for Colleagues

\begin{tabular}{|c|c|c|c|c|c|c|c|c|c|}
\hline Metaphor & Image & I1 & I2 & I3 & I4 & I5 & I6 & I7 & I8 \\
\hline Tiger and sheep & leadership and obedience & $\checkmark$ & & & & & & & \\
\hline Ant & cooperation, productivity & & $\checkmark$ & & $\checkmark$ & & & & \\
\hline Passive resistance & dissatisfaction, not change & & & $\checkmark$ & & & & & \\
\hline Bee & cooperation, productivity & & & & $\checkmark$ & & & & \\
\hline Student & learning, development & & & & & $\checkmark$ & & & \\
\hline Assistant & cooperation, solidarity & & & & & & $\checkmark$ & & \\
\hline Aquarium & teamwork and cooperation & & & & & & & $\checkmark$ & \\
\hline Assistant & solidarity, help each other & & & & & & $\checkmark$ & & $\checkmark$ \\
\hline
\end{tabular}

As can be seen in Table 6, one of the themes that can be concluded from the metaphors used for the colleagues was cooperation. In this regard, metaphors including "ant, bee, assistant, and aquarium" were used by the participants. The statements of the participants related to this theme were as follows: 
"The crowd of people constantly busy like ants working all together." (I2)

"Here, I have colleagues of a very different nature, like everywhere people are, but the most basic common feature, everyone here is a bee or ant, working all together." (I4)

"I see my colleagues as people helping each other so they are the assistant of each other." (I6)

"As everywhere, we have teachers who are different from each other but help each other like an aquarium with different kinds of fish." (I7)

"My colleagues are medical assistants worried about creating something out of nothing with their materials in the middle of an education system that has fallen apart." (I8)

Three participants used the metaphors "ant, bee and student" in order to emphasize the productivity and improvement for their colleagues. The statements of the participants related to this theme were as follows:

"They rush around all the time though little of their products are seen; they are always working and creating" (I2)

"They always produce something". (I4)

"I can compare lecturers to students. These students, who are constantly learning, realize that they are part of a whole and are aware of the importance of working together for common interests. " (I5)

One participant focused on the differences between the characteristic/ideologies of the colleagues using "tiger" for some of them and "sheep" for the others saying "I can say sheep for some of my colleagues because they obey every attempt, and tiger for others as they are stronger"

One participant used "passive resistance" and focused on the fact that the instructors are not satisfied with their work but do not do anything to change this situation saying "The passive resistance because they are unhappy to be here but do nothing about their unhappiness and they are not going anywhere else."

\section{Metaphors for Organizational Climate}

Metaphors that participants used to describe the organizational climate of their current workplace are described in Table 7.

Table 7. Metaphors for Organizational Climate

\begin{tabular}{|c|c|c|c|c|c|c|c|c|c|}
\hline Metaphor & Image & I1 & I2 & I3 & I4 & I5 & I6 & I7 & I8 \\
\hline Ecosystem & cooperation, help & $\checkmark$ & & & & & & & \\
\hline Village & sincere friends, happy place & & $\checkmark$ & & & & & & \\
\hline Government office & rules and regulations & & & $\checkmark$ & & & & & \\
\hline Clock & rules and deadlines & & & & $\checkmark$ & & & & \\
\hline Classroom & learn together & & & & & $\checkmark$ & & & \\
\hline Beehive & cooperation, help, solidarity & & & & & & $\checkmark$ & & \\
\hline Degraded natural wonder & happy, destroyed & & & & & & & $\checkmark$ & \\
\hline Autocracy & rules and regulations & & & & & & & & $\checkmark$ \\
\hline
\end{tabular}

As it is seen in Table 7, three participants used negative metaphors like "government office, clock and autocracy" in order to emphasize the pressure of rules and regulations in the organization. The following sentences can be given as examples to the opinions of the participants on this theme:

"Not always, but sometimes I see it as a government office where even the smallest business is hard to complete because of the intensity of the bureaucracy." (I3)

"Everything is planned minute by minute here and you do not have a chance to spend 1 hour without any schedules predetermined, so it is a clock" (I4)

"This place can be described as autocracy. The most accurate explanation I know is that decision and control mechanisms work far from merit, accountability and a philosophy. "(I8)

Two participants focused on the solidarity and cooperation within the institution using the metaphors "ecosystem and beehive". The statements of the participants are as follows:

"I see it as the ecosystem because everybody needs everybody, and when a part of the system breaks down, things start to fall apart after a while." (II)

"It's like a beehive. Everyone knows their job and fulfills their responsibilities (overwhelmingly, there are exceptions, of course). In this way, everyone helps the whole." (I6)

Two participants focused on the peaceful working environment. In this regard, I2 said "A happy village with many possibilities built far from the city". On the other hand, PI explained the peace among 
colleagues and emphasized the negative impact of the administrator saying "I think of a natural wonder, an idyllic bay. When I talk about preparatory school, I think of the bulldozers coming and flattening it and depriving it of those natural beauties."

One participant focused on improvement and learning and used the metaphor "classroom" saying "I think I can compare the working environment of the institution to a classroom full of interconnected and influencing students, with teachers at their head and trying to learn and do things together."

\section{CONCLUSION, DISCUSSION AND RECOMMENDATIONS}

In the study, the views of the instructors of English about the organizational climate at school of foreign languages were investigated. In order to investigate the organizational climate of the organization in detail, the current study reveals the problems encountered in the working environment, the satisfactory features in the working environment, the common power sources used by administrator, and the metaphors for administrators, colleagues and the climate of the organization respectively. The overall results of the study show that organizational structure, leadership, communication and relations among employees, and power sources used by the administrator are important factors on the organizational climate of school of foreign languages.

The main problems encountered in the working environment were administrator related problems, communication related problems and organizational structure related problems. It has been revealed that unjust administrative behaviors lead to negative organizational climate. This result is in line with the conclusion made by Tofur and Balıkçı (2018) that the damaged sense of justice in the administration negatively affects the organizational climate. For communication, it was concluded that inefficient communication trigger negative climate within the organization, which is in line with the conclusion made by Tofur and Balıkçı (2018) that unhealthy communication leads to problems in the organizational climate. Within the scope of organizational structure, it has been concluded that unclear job descriptions, frequent administrative changes and having many different administrators cause negative organizational climate. Similarly, Yaman (2010) states the problem of unclear job descriptions as a factor that causes negative organizational climate by increasing mobbing practices. In the context of organizational structure, another factor affecting the organizational climate has been identified as rewardpunishment policies and concluded that unstandardized punishment policies implemented within the organization lead employees to feel insecure and perceive a negative climate.

As for the satisfactory features in the working environment, the participants stated the importance of the communication among employees, organizational structure, colleagues, the work itself, and the supportive and positive administrators. Within the scope of communication, it has been revealed that effective communication, positive relations among employees, and the use of open communication channels contribute to the organizational climate positively. This result supports the conclusion made by Soylu Şiray (2013) that positive communication processes between employee-manager and employeeemployee contribute to a supportive and positive organizational climate, and lecturers working with a supportive administrator feel less stressed within the institution. Tofur and Balıkçı (2018) also concludes that heathy communication networks and solidarity create a positive organizational climate while the opposite leads to problems in the organizational climate. As for the organizational structure, it has been concluded that standardized reward-punishment policies lead the organizational climate to be perceived positively. Kasırga and Özbek (2008) also state that the material and moral rewards used by the administrators positively affect the organizational climate by increasing the morale and motivation of the employees. It was also found out that relations among colleagues influence the climate. This result becomes more meaningful with the conclusion made by Bucak (2002) that relations among employees are significant to the climate within the organization. In addition, it has been concluded that leadership skills have an effect on the organizational climate. In this context, it has been found out that administrators with strong leadership skills and expertise contribute to a positive organizational climate. As Küçük (2008) states that success-oriented, supportive and participatory leader behaviors affect the organizational climate positively. In the same way, Şişman (2002) states that the presence of administrators with strong instructional leadership skills contributes positively to the organizational climate by supporting the communication between colleagues, the teaching process and the teachers.

Another result of the study shows that power sources used by the administrators have both positive and negative effects on the organizational climate. According to the results of the study, it has 
been concluded that using legal power and power of expertise contribute to positive climate while coercive power and powerlessness lead to negative climate. This result becomes more meaningful with the research by Gül (2008) which concludes that the administrators informing all academic staff about the decisions taken and the current situations contribute positively to the climate perception. Similarly, Küçük (2008) and Tofur and Balıkçı (2018) conclude in their studies that in the organizations where leaders that allow employees participate in the decision-making process, climate is perceived as positive.

In order to understand the perceptions of participants towards organizational climate and to be able to interpret their views, metaphorical questions were also included in the study and the overall result of the metaphorical questions show that participants have negative perceptions towards administrators and the climate in the organization while they attribute positive meaning to colleagues.

As a result of the metaphors participants have used for their administrators, some inferences can be made about the organizational climate. It was found out that generally negative metaphors such as dictators, axe, politicians, and baseball bats were used for the administrators. In this case, it can be inferred that Instructors of English working at school of foreign languages perceive a negative organizational climate due to authoritative leadership style, low motivation rate, and serious rules within the organization. These findings are similar to Yaman's (2010) study in which harmful creatures were used as metaphors for administrators.

Likewise, negative metaphors such as degraded natural wonder, autocracy, government office, clock were used by the participants for the organizational climate. It was also found out that the most common power source used by the administrators is the legal power and the administrative related problems including unfair administration style, mobbing, incompetence, lack of leadership skills, authoritarian administrative approach; problems based on organizational structure including ambiguity in job description, non-standard reward-punishment policies, too many executive positions and frequently changed administrators, and communication-related problems caused by poor communication skills and disrespect. As a result, instructors may feel that they work in a closed and autocratic organizational structure, which causes them to have a negative view of the organizational climate. It can be said that these findings support the findings of Yaman (2010) whose research results revealed that universities have a negative organizational climate.

Most of the participants used positive metaphors such as aquarium, bee, ant, student, and aid for their colleagues, which could reveal an open and democratic organizational climate. This positive situation may be important to increase the efficiency of the education in school of foreign languages. Thus, it can be said that an effective administration could help the staff in school of foreign languages work in line with the organizational aims.

In conclusion, the findings could give clues about the views of the instructors of English in school of foreign languages towards the organizational climate. Considering the research data, it can be suggested that a democratic administrative approach with leadership qualities and competence, clear organizational structure, open communication networks and being open to the involvement of employees to the administrative decisions can support the positive organizational climate and contribute to the effectiveness and continuity of the organization.

In this study, views of instructors of English working in school of foreign languages in different foundations universities in Ankara on organizational climate were investigated. Only instructors working in foundation universities in Ankara took part as the participants of the study, so it is suggested for future researchers to also work with participants from the schools of foreign languages in state universities, the organization of which is quite different from the foundation universities.

It can also be suggested that researchers who will conduct research on this subject should conduct separate case studies or action studies for each school of foreign languages focused on improving the organizational climate in a positive way.

\section{Ethics Committee Approval Information}

In this research, the data were gathered through interviews between June 2018 and September 2018. The participants were interviewed individually. A semi-structured interview form developed by the researcher was used in the interviews and interviews lasted between 45 minutes and 75 minutes. Ethical values were taken into consideration while collecting the data. The article was submitted to the journal in 2021. Since the data belong to pre-2020, Ethics Committee Permission was not obtained for the study according to the decision of TUBITAK ULAKBİM TR DİZIN. Another reason for not obtaining Ethics 
Committee Permission is that it is difficult to obtain an Ethics Committee Permission retrospectively. These topics have been reported in the journal Asya Studies.

\section{REFERENCES}

Abu-Saad, İ. and Hendriks, V. (1995). Organizational Climate and Teachers' Job Satisfaction in a Multicultural Milieu: The Case of the Bedouin Arab Schools in Israel. Int. J. Educational Development, 15(2), 141153.

Açıkalın, Ş. (1993). Öğretmenlerin Okul Müdürlerini Etkileme Güçleri (Ankara İli Örneği). Hacettepe Üniversitesi Eğitim Fakültesi Dergisi, 0(9), 183-192.

Akıncı-Vural, Z. B. (2003). Kurum Kültürü̈. İstanbul: İletişim Yayınları.

Arabac1, İ. B. (2011), Organizational Climate of Firat University. International Online Journal of Educational Sciences, 3(1), 161-180.

Ayık, A., and Şayir, G. (2014). Okul Müdürlerin Öğretimsel Liderlik Davranışları İle Örgüt İklimi Arasındaki İlișki. Elektronik Sosyal Bilimler Dergisi, 13(49), 253-279.

Babu, A. and Kumari, M. (2013). Organizational Climate as a Predictor of Teacher Effectiveness. European Academic Research, 1(5), 553- 568.

Bakan, İ. and Büyükbeşe, T. (2010). Liderlik Türleri ve Güç Kaynaklarına İlişsin Mevcut- Gelecek Durum Karşılaştırması: Eğitim Kurumu Yöneticilerinin Algılarına Dayalı Bir Alan Araştırması. KMÜ Sosyal ve Ekonomik Araştrrmalar Dergisi, 12(19), 73-84.

Bucak, E.B. (2002). Abant İzzet Baysal Üniversitesi Eğitim Fakültesinde Örgüt İklimi: Yönetimde Ast- Üst İlişkileri. Muğla Üniversitesi SBE Dergisi Bahar, 0(7), 0-0.

Bursalığlu, Z. (2008). Okul Yönetiminde Yeni Yapı ve Davranış. Ankara: Pegem Yayıncılık.

Büte, M. (2011). Algılanan Örgüt İkliminin Etik Olmayan Davranışlar Üzerindeki Etkilerinin Belirlenmesine Yönelik Bir Araştırma. Atatürk Üniversitesi İktisadi ve İdari Bilimler Dergisi, 25(2), 103-122.

Çağlar, M. E. (2008). Örgütsel İklimin Örgütsel Bağlllık Üzerindeki Etkileri, (Yayımlanmamış Yüksek Lisans Tezi), (Danışman: Prof. Dr. Birol Bumin), Ankara: Gazi Üniversitesi Sosyal Bilimler Enstitüsü.

Çetin, M. and Sılay, N. (2005). Yüksek Öğretimde Örgüt İklimine Yönelik Akademik Algılar. KSÜ Sosyal Bilimler Dergisi, 2(2), 1-8.

Chen, G. and Weikart, L.A. (2008). Student Background, School Climate, School Disorder, and Student Achievement: An Empirical Study of New York City's Middle Schools. Journal of School Violence, 7(4), 3-20.

Ertekin, Y. (1978). Örgüt İklimi. Ankara: Doğan Basımevi.

Glisson, C. and Hemmelgarn, A. (1998). The Effect of Organizational Climate and Interorganizational Coordination on the Quality and Outcomes of Children's Service System. Child Abuse and Neglect, 22(5), 401-421.

Gül, H. (2008). Organizational Climate and Academic Staff's Perception on Climate Factos. Humanity and Social Sciences Journal 3(1), 37-48.

Gürkan, Ç. (2006). Örgütsel Bağll1ı: Örgütsel İklimin Örgütsel Bağlllık Üzerindeki Etkisi ve Trakya Üniversitesi'nde Örgüt İklimi ile Örgütsel Bağllık Arasındaki İlişkinin Araştırılması, (Yayımlanmamış Yüksek Lisans Tezi), (Danışman: Prof. Dr. Yaşar Sucu), Edirne: Trakya Üniversitesi Sosyal Bilimler Enstitüsü.

Halpin, A. W. and D. B. Croft. (1963). The Organizational Climate of Schools. Chicago: Midwest Administration Center.

İpek, C. (2014). Örgütsel Çatışma ve Çatı̧̧ma Yönetiminde Uygulanabilecek Örgüt Geliştirme Araçları. (Editörler: Cevat Elma and Kamile Demir). Yönetimde Çağdaş Yaklaşımlar Uygulamalar ve Sorunlar İçinde (235-269). Ankara: Anı Yayıncılık.

Jones, A. and Shindler, J. (2016). Exploring the School Climate--Student Achievement Connection: Making Sense of Why the First Precedes the Second. Educational Leadership and Administration: Teaching and Program Development, 0(27), 35-51.

Karcılığlu, F. (2001). Örgüt Kültürü ve Örgüt İklimi İlişkisi. Atatürk Üniversitesi İktisadi ve İdari Bilimler Dergisi 15(1-2), 265-283.

Kasırga, İ. and Özbek, O. (2008). Beden Eğitimi ve Spor Yüksekokullarında Örgüt Iklimi. Spormetre Beden Eğitimi ve Spor Bilimleri Dergisi, 6(2), 59-68.

Küçük, M. (2008). Eğitim Kurumlarında Yöneticilerin Liderlik Davranışlarının Örgüt İklimi Üzerine ve Eğiticilerin Performansına Etkisi, (Yayımlanmamış Yüksek Lisans Tezi), (Danışman: Yrd. Doç. Dr. Saih Zeki İmamoğlu), İstanbul: Beykent Üniversitesi Sosyal Bilimler Enstitüsü.

Litwin, G. H. and Stringer, R. A. (1968), Motivation and Organizational Climate. Cambridge, MA: Harvard Business School, Division of Research. 
Lunenberg, C.L. and Orstein, A.C. (2013). Eğitim Yönetimi Kavramlar ve Uygulamalar, (6. Baskı). (Çev. Gökhan Arastaman). Ankara: Nobel Akademik Yayıncılık. (2004.)

Miles, M.B. and Huberman, A.M. (1994). An Expended Sourcebook: Qualitive Data Analysis, (2 ${ }^{\text {nd }}$ Edition). London: Sage Publishing.

Morrison, K. (2002). School Leadership and Complexity Theory. New York: Routledge.

Nartgün, Ş. S. (2006). Öğretim Elemanlarının Örgütsel Değerlere İlişkin Görüşler (Abant İzzet Baysal Üniversitesi Eğitim Fakültesi Örneği). Değerler Ĕ̆itimi Dergisi, 4(12), 129-148.

Oldham, G.R. and Cummings, A. (1996). Employee Creativity: Personal and Contextual Factors at Work. Academy of Management Journal, 0(39), 607-634.

Özçiçek, V. T. (2016). Örgüt İklimini Etkileyen İç Etmenler, (Yayımlanmamış Yüksek Lisans Tezi), (Danışman: Doç. Dr. İbrahim Kocabaş), İstanbul: İstanbul Aydın Üniversitesi ve Yıldız Teknik Üniversitesi Sosyal Bilimler Enstitülerinin Ortak Yürüttügü Eğitim Yönetimi ve Denetimi Anabilim Dalı Eğitim Yönetimi ve Denetimi Tezli Yüksek Lisans Programı.

Özdede, A. (2010). Bir Yükseköğretim Kurumunda ISO 9001:2000 Belgesine Sahip Olan ve Olmayan Birimler Arasındaki Örgüt İklimi Farklılıkları: Dokuz Eylül Üniversitesi Örneği, (Yayınlanmamış Yüksek Lisans Tezi), (Danışman: Yrd. Doç. Dr. Habil Gökmen), İzmir: Dokuz Eylül Üniversitesi Sosyal Bilimler Enstitüsü.

Özdemir, F. (2006). Örgütsel Iklimin Iş Tatmin Düzeyine Etkisi: Tekstil Sektöründe Bir Araştırma, (Yayımlanmamış Doktora Tezi), (Danışman: Doç. Dr. Ünal Ay), Adana: Çukurova Üniversitesi.

Özdemir, S. and Cemaloğlu, N. (2017). Örgütsel Davranışve Yönetimi, (2.Baskı). Ankara: Pegem Akademi Yayıncilik.

Raza, S. A. (2010). Impact of Organizational Climate on Performance of College Teachers in Punjab. Journal of College Teaching and Learning, 7(10), 47-52.

Scheineder, B. and Barbera, K. (2014). The Oxford Handbook of Organizational Climate and Culture. New York: Oxford University Press.

Şişman, M. (2002). Öğretim Liderliği. Ankara: Pegem Yayıncılık.

Soylu Şiray, E. (2013). Relationship Between the Organizational Climate and Occupational Stress Experienced By English Instructors in the Preparatory Schools of Five Universities in Ankara, (Unpublished Doctorate Thesis), (Supervisor: Asst. Prof. Dr. Gökçe Gökalp), Ankara: Middle East Technical University, Enstitute of Social Sciences.

Süslü-Kalafat, Ş. (2017). Üniversitelerdeki İngilizce Okutmanlarının Örgütsel İklim Algıları İle Mesleki Tükenmişlik Düzeyleri Arasındaki İlişki, (Yayımlanmamış Doktora Tezi), (Danışman: Prof. Dr. Yüksel Kavak), Ankara: Hacettepe Üniversitesi Eğitim Bilimleri Enstitüsü.

Thomas, J. C. (2008). Administrative, Faculty and Staff Perceptions of Organizational Climate and Commitment in Christian Higher Education. Christian Higher Education, 7(3), 226-252.

Tofur, S. and Balıç̧ı, A. (2018). Okul Yöneticileri ve Öğretmenlere Göre Okul Iklimini Etkileyen Faktörlerin Incelenmesi: Ortaokul Örneği. Turkish Studies Educational Sciences, 13(11), 1279-1291.

Türkmenoğlu, İ. (2013). Pozitif Yönetim: Issyerinde Keyifli Ortam Yaratmak, (4.Bask1). Ankara: Sözkesen Matbaacılık Tic. Ltd. (e-kitap: 2011).

Ural, A. (2014). Gazi Üniversitesinde Örgütsel Iklim. Amme İdaresi Dergisi, 47(2), 145-165.

Varol, M. (1989). Örgüt Kültürü ve Örgüt İklimi. Ankara Üniversitesi Siyasal Bilgiler Fakültesi Dergisi, 44(12), 195-222.

Yaman, E. (2010). Psikoşiddete (Mobbinge) Maruz Kalan Öğretim Elemanlarının Örgüt Kültürüne ve İklimine İlişkin Algıları. Kuram ve Uygulamada Eğitim Bilimleri, 10(1), 547-578.

Yıldırım, A. and Şimşek, H. (2016). Sosyal Bilimlerde Nitel Araştırma Yöntemleri, (10.Baskı). Ankara: Seçkin Yayıncılik (1999.)

Zhang, J. and Liu, Y. (2010). Organizational Climate and Its Effects on Organizational Variables: An Empirical Study. International Journal of Psychological Studies, 2(2), 189-201. 